\title{
PENERAPAN METODE DISKUSI KELOMPOK UNTUK MENINGKATKAN HASIL BELAJAR IPA DAN AKTIVITAS SISWA KELAS IV SD I SIDOREKSO PADA MATERI MENGGOLONGKAN HEWAN BERDASARKAN JENIS MAKANANNYA
}

\author{
Jamaludin Malik ${ }^{1}$ \\ SD 1 Sidorekso Kaliwungu Kudus \\ Email: jamaludinmalik1965@gmail.com
}

\section{Info Artikel}

\section{Sejarah Artikel:}

Diterima 1 Maret 2019

Direvisi 29 Mei 2019

Disetujui 29 Mei 2019

\section{Keywords:}

Science learning outcomes, learning activities, and group discussion methods.

\begin{abstract}
The purpose of this study was to determine the improvement of learning outcomes of science materials classifying animals based on the type of food using group discussion methods in fourth grade students of SD 1 Sidorekso as well as to improve student learning activities especially in the first semester of 2015/2016 science lessons.

The research method used is classroom action research. The research subjects were 27 students. Data collection techniques using the test method. The analysis technique goes through two stages, namely 1) using comparative descriptive analysis techniques and 2) using observation techniques with descriptive analysis based on the results of observation and reflection. The study carried out two cycles from July to September 2015. Each cycle includes four stages of activity, namely planning (planning), implementing actions (acting), observing (observing) and reflection (reflecting).

The results showed that the learning outcomes of science about classifying animals based on their type of food using group discussion methods in fourth grade students of SD 1 Sidorekso could increase. From the initial conditions, the average formative test score is 61.48 with the percentage completed $29.63 \%$ and the percentage of tifak complete $70.37 \%$. The results of the first cycle increased by an average of 68.15 with a complete percentage of $66.67 \%$ and the percentage did not complete $33.33 \%$. The results of the second cycle rose to 73.70 with the percentage completed $96.30 \%$ and the percentage did not complete $3.70 \%$. Conclusion of group discussion methods can improve science learning outcomes and student activities.
\end{abstract}

\begin{abstract}
Abstrak
Tujuan penelitian ini untuk mengetahui peningkatkan hasil belajar IPA materi menggolongkan hewan berdasarkan jenis makanannya menggunakan metode diskusi kelompok pada siswa kelas IV SD 1 Sidorekso serta untuk meningkatkan aktivitas belajar siswa khususnya pada pelajaran IPA Semester 1 Tahun Pelajaran 2015/2016.

Metode penelitian yang digunakan yakni penelitian tindakan kelas. Subjek penelitian sebanyak 27 siswa. Teknik pengumpulan data dengan metode tes. Teknik analisis melalui dua tahap, yaitu 1) menggunakan teknik analisis deskriptif komparatif dan 2) menggunakan teknik observasi dengan analisis diskriptif berdasarkan hasil observasi dan refleksi. Penelitian dilaksanakan dua siklus pada bulan Juli sampai dengan September 2015. Masing-masing siklus meliputi empat tahap kegiatan, yaitu perencanaan (planning), pelaksanaan tindakan (acting), pengamatan (observing) dan refleksi (reflecting).

Hasil penelitian menunjukan bahwa hasil belajar IPA tentang menggolongkan hewan berdasarkan jenis makanannya dengan menggunakan metode diskusi kelompok pada siswa kelas IV SD 1 Sidorekso dapat meningkat. Dari kondisi awal rata-rata nilai tes formatif 61,48 dengan persentase tuntas $29,63 \%$ dan persentase tifak tuntas $70,37 \%$. Hasil siklus I meningkat rata-rata 68,15 dengan persentase tuntas $66,67 \%$ dan persentase tidak tuntas $33,33 \%$. Hasil siklus II rata-rata naik menjadi 73,70 dengan persentase tuntas $96,30 \%$ dan persentase tidak tuntas 3,70\%. Simpulan metode diskusi kelompok dapat meningkatkan hasil belajar IPA dan aktivitas siswa.
\end{abstract}

(C) 2019 Universitas Muria Kudus 
Malik, Jamaludin

PENERAPAN METODE DISKUSI KELOMPOK UNTUK MENINGKATKAN ...

REFLEKSI EDUKATIKA : Jurnal Ilmiah Kependidikan, Volume 9, Nomor 2, Juni 2019, hlm 128-133

\section{PENDAHULUAN}

Pembelajaran IPA pada kompetensi dasar menggolongkan hewan berdasarkan jenis makanannya telah peneliti laksanakan pembelajarannya dengan menggunakan metode ceramah, tanya jawab, dan pemberian tugas. Selama pembelajaran berlangsung diketahui bahwa banyak siswa yang pasif, tidak mau mengemukakan gagasan, bertanya, apalagi menanggapi pertanyaan sehingga pembelajarannya kurang menyenangkan apalagi bermakna.

Proses pembelajaran yang demikian berdampak pada hasil belajar siswa sehingga berdasarkan hasil tes formatif yang diikuti oleh 27 siswa diketahui bahwa hanya delapan siswa yang mendapat nilai diatas kriteria ketuntasan minimal yang ditetapkan yakni sebesar 70. Rendahnya ketuntasan belajar IPA materi menggolongkan hewan berdasarkan jenis makanannya membuat peneliti ingin memperbaiki hasil belajar dan aktivitas siswa dengan melaksanakan penelitian tindakan kelas.

Berdasarkan latar belakang diatas maka rumusan masalah penelitian ini yaitu Bagaimana penerapan metode diskusi kelompok dapat meningkatkan aktivitas dan hasil belajar siswa tentang menggolongkan hewan berdasarkan jenis makanannya pada siswa kelas IV SD 1 Sidorekso semester 1 Tahun Pelajaran 2015//2016 ?. Adapun tujuan penelitian ini yakni untuk meningkatkan aktivitas dan hasil belajar IPA tentang menggolongkan hewan berdasarkan jenis makanannya menggunakan metode diskusi kelompok pada siswa kelas IV SD 1 Sidorekso Semester 1 Tahun Pelajaran 2015/2016.

\section{METODE PENELITIAN}

Metode penelitian yang digunakan yakni penelitian tindakan kelas. Subjek penelitian sebanyak 27 siswa. Teknik pengumpulan data dengan mendeskripsikan hasil tes dilakukan secara langsung kepada siswa untuk memperoleh data tentang hasil belajar siswa pada proses pembelajaran secara benar dan tepat. Metode tes digunakan untuk memperoleh data tentang tingkat kemampuan penguasaan materi pembelajaran sebelum dan sesudah pembelajaran.

Teknik analisis melalui dua tahap, yaitu 1) menggunakan teknik analisis deskriptif komparatif yaitu membandingkan hasil observasi kondisi awal, siklus I dan siklus II, sehingga setelah dibandingkan hasil siklus I dan hasil siklus II ada perbedaan dan peningkatan; dan 2) menggunakan teknik observasi dengan analisis diskriptif berdasarkan hasil observasi dan refleksi. Selanjutnya dari hasil belajar siswa nilai sebelum dilaksanakan pembelajaran metode diskusi kelompok dibandingkan dengan hasil sesudah dilaksanakan pembelajaran metode diskusi kelompok untuk mengetahui kemajuan hasil yang dicapai dalam pembelajaran. Ketercapaian hasil penelitian ini dengan Indikator keberhasilan tindakan kelas tampak apabila peningkatan hasil belajar mencapai 75\% ketuntasan dari jumlah siswa dengan nilai di atas KKM (70) dan peningkatan aktivitas belajar siswa mencapai $85 \%$.

Penelitian dilaksanakan dua siklus pada bulan Juli sampai dengan September 2015. Masing-masing siklus meliputi empat tahap kegiatan, yaitu perencanaan (planning), pelaksanaan tindakan (acting), pengamatan (observing) dan refleksi (reflecting). Dalam perencanaan ini meliputi kegiatan identifikasi masalah, menganalisis penyebab masalah dan menetapkan tindakan pemecahannya

Beberapa kegiatan yang dilakukan dalam observasi awal untuk mengidentifikasi masalah yaitu melalui wawancara dengan siswa. Berdasarkan analisis terhadap masalah yang ditemukan kemudian ditentukan metode yang akan digunakan yaitu melalui penggunaan model pembelajaran diskusi kelompok di kelas IV SD 1 Sidorekso tahun pelajaran 2015/2016.

Langkah-langkah persiapan selanjutnya membuat skenario pembelajaran dengan menyusun Rencana Pelaksanaan Pembelajaran (RPP) yang terdapat proses pembelajaran model diskusi kelompok. Pelaksanaan tindakan (acting) dilaksanakan skenario pembelajaran yang telah direncanakan. Pada tiap-tiap siklus yaitu menerapkan pembelajaran menggunakan model pembelajaran diskusi kelompok. Siklus II merupakan hasil pengembangan atas refleksi hasil siklus I.

Pengamatan (observing) pada kegiatan ini peneliti dibantu oleh satu orang observer untuk melaksanakan observasi terhadap pelaksanaan tindakan untuk mengetahui sejauh mana penguasaan siswa dalam pembelajaran. Pelaksanaan Observasi 
Malik, Jamaludin

PENERAPAN METODE DISKUSI KELOMPOK UNTUK MENINGKATKAN ...

REFLEKSI EDUKATIKA : Jurnal Ilmiah Kependidikan, Volume 9, Nomor 2, Juni 2019, hlm 128-133

bersamaan pelaksanaan tindakan dengan menggunakan lembar observasi yang telah dibuat. Aspek-aspek yang diamati adalah aktivitas siswa selama proses pembelajaran berlangsung serta hasil tes pada akhir siklus. Hasil analisis data yang dilaksanakan dalam tahap ini digunakan sebagai acuan untuk melaksanakan siklus berikutnya.

Refleksi (reflecting) hasil dan tahap observasi yang meliputi aktifitas siswa selama proses belajar mengajar, hasil tes pada akhir siklus juga kendala-kendala yang dihadapi selama kegiatan pembelajaran dikumpulkan serta dikaji sehingga diperoleh hasil refleksi kegiatan untuk mengetahui perubahan yang terjadi selama menerapkan pembelajaran ini. Hasil analisis data yang dilaksanakan dalam tahap ini digunakan sebagai acuan untuk melaksanakan siklus berikutnya. Penelitian ini menggunakan model penelitian tindakan kelas yang digambarkan dalam bagan sebagai berikut: (Gambar 1).

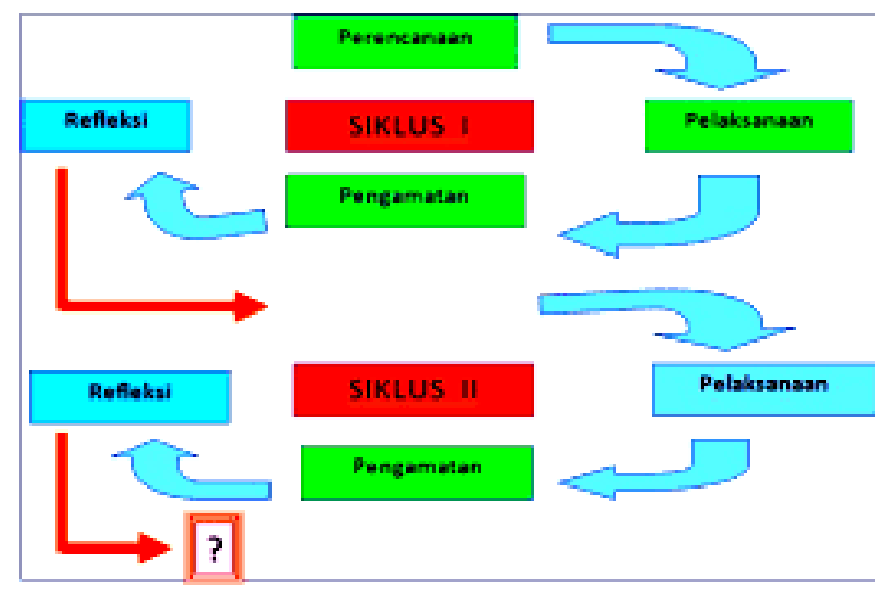

Gambar 1. Alur Penelitian

(Sumber: Arikunto, 1998)

\section{HASIL DAN PEMBAHASAN}

Hasil tes prasiklus menunjukkan nilai terendah 40 dan tertinggi 80. Sedangkan skor rata-rata kelas yang diperoleh sebesar 61,48 ketuntasan belajar klasikal yang dicapai siswa hanya 8 siswa atau sebesar $29,63 \%$ dari 27 siswa.

Aktivitas belajar siswa, pada kondisi awal dimana pelaksanaan pembelajaran IPA yang dilakukan oleh guru masih menggunakan metode ceramah atau masih banyak siswa yang pasif, kurang perhatian dan sebagian siswa mengantuk, sehingga aktivitas belajar siswa masih rendah. Sedangkan hasil belajar siswa pada kondisi awal atau saat ulangan harian pertama nilai kognitif siswa dari jumlah siswa yang tuntas (memenuhi KKM) atau rata-rata klasikal: $29,63 \%$. Hasil tersebut masih di bawah kriteria ketuntasan klasikal yang ditetapkan di sekolah sebesar $75 \%$.

Rendahnya nilai rata-rata siswa yang masih di bawah KKM dan tingkat ketuntasan belajar yang rendah maka peneliti melakukan penelitian tindakan kelas. Dalam penelitian tersebut peneliti menerapkan metode diskusi kelompok. Hasil penilaian dengan pembelajaran yang dilakukan oleh guru melalui metode diskusi kelompok pada siklus I diperoleh skor tes berikut.

Tabel 1. Hasil Belajar Siswa Siklus I

\begin{tabular}{lllll}
\hline & Rentang Nilai & Kategori & $\begin{array}{l}\text { Frekuens } \\
\text { i }\end{array}$ & Persentase \\
\hline 1 & $90-100$ & Sangat baik & 0 & $0 \%$ \\
2 & $80-89$ & Baik & 6 & $22 \%$ \\
3 & $70-79$ & Cukup & 12 & $45 \%$ \\
4 & $\leq 69$ & Kurang & 9 & $33 \%$ \\
\hline & Jumlah & & 27 & $100 \%$ \\
\hline
\end{tabular}


Malik, Jamaludin

PENERAPAN METODE DISKUSI KELOMPOK UNTUK MENINGKATKAN ...

REFLEKSI EDUKATIKA : Jurnal Ilmiah Kependidikan, Volume 9, Nomor 2, Juni 2019, hlm 128-133

Hasil observasi aktivitas siswa pada pelaksanaan tindakan siklus I dengan menerapkan Diskusi Kelompok pada pembelajaran Menggolongkan hewan berdasarkan jenis makanannya kelas IV SD 1 Sidorekso Kudus diperoleh data sebagai berikut:

Tabel 2 Rekapitulasi Aktivitas Siswa Siklus I

\begin{tabular}{lllll}
\hline \multirow{2}{*}{ No } & Indikator & \multicolumn{2}{l}{ Perolehan Skor } & Rata2 \\
\cline { 3 - 5 } & Pert I & Pert II & Siklus I \\
\hline 2 & Keantusiasan siswa mengikuti pelajaran & 3,2 & 3,3 & 3,25 \\
\hline 3 & Keaktifan siswa dalam bertanya pada guru & 2,9 & 3,2 & 3,05 \\
\hline 4 & Kemampuan siswa bekerjasama kelompok & 2,9 & 3,1 & 3,00 \\
\hline 5 & Mempresentasikan hasil kerja kelompok & 2,9 & 3,2 & 3,05 \\
\hline & Menanggapi hasil kerja kelompok lain & 3,2 & 3,3 & 3,25 \\
\hline & Jumlah skor & 15,10 & 16,10 & 15,6 \\
\hline & Pata-rata & 3,02 & 3,22 & 3,12 \\
\hline & Kriteria & $75,50 \%$ & $80,50 \%$ & $78,00 \%$ \\
\hline
\end{tabular}

Berdasarkan data pada Tabel 2 di atas, dapat diketahui persentase keseluruhan aktivitas belajar siswa pada siklus I sebesar $78,00 \%$ dengan persentase aktivitas pertemuan I sebesar 75,50\% serta persentase aktivitas pertemuan II sebesar 80,50\%. Dari data tersebut dapat disimpulkan bahwa hasil observasi aktivitas belajar siswa belum berhasil untuk mencapai indikator yang ditentukan pada aktivitas belajar siswa yaitu sebesar $\geq 85 \%$.

Berdasarkan data skor tes dan ketuntasan belajar pada pembelajaran yang dilakukan di dalam kelas sudah menunjukkan adanya peningkatan. Pembelajaran yang dilakukan pada prasiklus hanya mencapai ketuntasan 29,63\% setelah diadakan pembelajaran siklus I ketuntasan menjadi 66,67\%. Beberapa kekurangan di antaranya: 1) masih banyak peserta didik yang pasif, baik bertanya kepada guru maupun kepada kelompok yang lain, 2) tidak semua kelompok melakukan presentasi, 3) Beberapa siswa kurang memperhatikan materi yang dijelaskan oleh guru serta masih kurang aktif ketika guru memberikan pertanyaan secara lisan. Karena ketuntasan belajar belum mencapai $75 \%$ dari jumlah siswa maka diadakan tindakan perbaikan pembelajaran siklus II dengan cara: 1) mengoptimalkan materi dengan menerapkan metode diskusi kelompok, 2) meminta kepada seluruh siswa untuk aktif dalam berdiskusi, karena penyelesaian lembar diskusi siswa yang diberikan guru adalah tanggung jawab seluruh anggota kelompok, 3) memberikan motivasi pada siswa untuk membacakan hasil diskusi, supaya lebih percaya diri dalam mempresentasikan hasil diskusi kelompok dengan penguatan positif, dan 4) efisiensi waktu dengan mengalokasikan yang tepat.

Kegiatan pembelajaran siklus II berlangsung sangat aktif, siswa antusias melakukan diskusi dan menyenangkan karena terjadi interaksi harmonis dalam satu kelompok maupun antar kelompok. Siswa saling menanggapi hasil temuan kelompok lain secara rasional dan berpendapat secara logis demokratis dengan metode pembelajaran diskusi kelompok.

Demikian juga untuk hasil belajar siswa pada siklus II sudah berhasil dengan baik dan telah mencapai target yang diharapkan yaitu $96,30 \%$ di atas kriteria ketuntasan klasikal yang ditetapkan di sekolah. Hasil prestasi belajar siswa tersebut menunjukkan sebagian besar siswa sudah menguasai materi menggolongkan hewan berdasarkan jenis makanannya.

Pada pembelajaran siklus II menunjukkan terjadinya peningkatan pada hasil belajar siswa. Ketuntasan belajar klasikal yang dicapai sebesar 96,30\% artinya masih ada 1 siswa $(3,70 \%)$ belum tuntas/mencapai nilai KKM. Hal ini dapat dilihat pada Tabel 3 berikut, 
Malik, Jamaludin

PENERAPAN METODE DISKUSI KELOMPOK UNTUK MENINGKATKAN ...

REFLEKSI EDUKATIKA : Jurnal Ilmiah Kependidikan, Volume 9, Nomor 2, Juni 2019, hlm 128-133

Tabel 3 Hasil Belajar Siswa Siklus II

\begin{tabular}{lllll}
\hline No & Rentang Nilai & Kategori & Frekuensi & Persentase \\
\hline 1 & $90-100$ & Sangat baik & 2 & $7 \%$ \\
2 & $80-89$ & Baik & 7 & $26 \%$ \\
3 & $70-79$ & Cukup & 17 & $63 \%$ \\
4 & $\leq 69$ & Kurang & 1 & $4 \%$ \\
\hline & Jumlah & & 20 & $100 \%$ \\
\hline
\end{tabular}

Aktivitas siswa pada siklus II ada peningkatan. Berdasarkan hasil observasi aktivitas siswa pada pelaksanaan tindakan siklus II dengan menerapkan metode diskusi kelompok pada pembelajaran IPA materi menggolongkan hewan berdasarkan jenis makanannya kelas IV SD 1 Sidorekso Kudus diperoleh data sebagai berikut.

Tabel 4 Rekapitulasi Aktivitas Siswa Siklus II

\begin{tabular}{|c|c|c|c|c|}
\hline \multirow[b]{2}{*}{ No } & \multirow[b]{2}{*}{ Indikator } & \multicolumn{2}{|c|}{ Perolehan Skor } & \multirow{2}{*}{$\begin{array}{l}\text { Rata2 } \\
\text { Siklus II }\end{array}$} \\
\hline & & Pert I & Pert II & \\
\hline 1 & Keantusiasan siswa mengikuti pelajaran & 3,7 & 3,8 & 3,75 \\
\hline 2 & Keaktifan siswa dalam bertanya pada guru & 3,6 & 3,8 & 3,70 \\
\hline 3 & Kemampuan siswa bekerjasama kelompok & 3,7 & 3,8 & 3,75 \\
\hline 4 & Mempresentasikan hasil kerja kelompok & 3,7 & 3,8 & 3,75 \\
\hline \multirow[t]{5}{*}{5} & Menanggapi hasil kerja kelompok lain & 3,6 & 3,7 & 3,65 \\
\hline & Jumlah skor & 18,3 & 18,9 & 18,60 \\
\hline & Rata-rata & 3,66 & 3,78 & 3,72 \\
\hline & Persentase & $91,50 \%$ & $94,50 \%$ & $93,00 \%$ \\
\hline & Kriteria & SB & SB & SB \\
\hline
\end{tabular}

\section{PEMBAHASAN TIAP SIKLUS}

Pada pembelajaran sebelum tindakan penelitian, peneliti hanya mengandalkan metode konvensional yaitu ceramah, tanya jawab, dan pemberian tugas, sehingga hasil yang dicapai adalah siswa yang memperoleh nilai di atas KKM hanya 8 dari 27 siswa atau 29,63\%. Dengan nilai terendah 40 , nilai tertinggi 80 dan nilai rata-rata 61,48 . Berdasarkan hasil tersebut peneliti bermaksud untuk meningkatkan hasil belajar siswa mata pelajaran IPA tentang menggolongkan hewan berdasarkan jenis makanannya dengan melaksanakan tindakan pembelajaran dengan pola PTK pada pembelajaran berikutnya.

Pada pembelajaran siklus I menerapkan model pembelajaran diskusi kelompok hasil tes formatif yang diperoleh dari 27 siswa ada 18 atau $66,67 \%$ siswa sudah tuntas belajar, sedangkan 9 siswa atau $33,33 \%$ belum tuntas belajar. Nilai rata-rata kelas yang diperoleh pada pembelajaran siklus I meningkat menjadi 68,15 dari sebelum perbaikan pembelajaran nilai rata-rata kelas hanya 61,48. Peneliti merefleksi sebab-sebab kegagalan dalam perbaikan pembelajaran siklus I, ternyata pada pembelajaran siklus I ditemukan hal-hal sebagai berikut: 1) siswa kurang dilibatkan dalam pembelajaran, 2) guru lebih aktif sendiri dalam pembelajaran, pembentukkan kelompok masih kurang kondusif, guru masih kurang dalam memberikan penguatan, 3) kegiatan diskusi kelompok belum berjalan dengan optimal, karena kerja kelompok yang dilakukan masih didominasi siswa yang pandai, 4) siswa yang ditunjuk kurang siap untuk mempresentasikan hasil diskusi dan menjawab pertanyaan guru.

Pada siklus I permasalahan yang hadapi dalam penerapan metode diskusi kelompok adalah siswa kurang berani dalam mengutarakan pendapat akibatnya siswa menjadi pasif dikarenakan takut salah. Cara yang digunakan untuk mengatasi hal tersebut: 1) peneliti meminta kepada seluruh siswa untuk aktif dalam berdiskusi, karena penyelesaian lembar diskusi siswa yang diberikan guru adalah tanggung jawab seluruh anggota kelompok, 2) memberikan motivasi pada siswa yang di panggil nomornya untuk membacakan hasil diskusi, supaya lebih percaya diri dalam mempresentasikan hasil diskusi kelompok dengan penguatan positif, 3) peneliti mengajak siswa untuk menanggapi setiap jawaban yang disampaikan oleh siswa yang membacakan hasil diskusi, 4) pada saat presentasi kelompok, peneliti mengajak seluruh kelompok untuk mendengarkan kemudian menanggapi hasil diskusi kelompok yang maju presentasi. 
Pelaksanaan tindakan siklus II diperoleh nilai tertinggi 90 dan nilai terendah 60 dengan nilai rata-rata 73,70 serta ketuntasan klasikal 96,30\%. Hal tersebut menunjukkan peningkatan jika dibandingkan dengan hasil belajar pada siklus I dengan nilai terendah 50 dan nilai tertinggi 80 dengan nilai rata-rata 68,15 serta ketuntasan klasikal sebesar 66,67\%.

Pada siklus II, terjadi perubahan sikap dan keterampilan belajar berupa keberanian siswa mengungkapkan pendapatnya dengan menggunakan catatan singkat dan ringkasan. Sebagian besar berani tampil di muka kelas untuk presentasi karena siswa yakin hasil pekerjaannya tidak salah. Siswa dapat melakukan komunikasi antar kelompok secara maksimal, artinya yang dulunya pendiam mau tidak mau harus aktif karena dengan menerapkan metode diskusi kelompok diharapkan terjalin komunikasi aktif antar siswa, semangat kebersamaan dan kerjasama, partisipasi dalam kerja kelompok, dan memaksimalkan hasil belajar siswa serta dukungan dan penguatan guru.

Penggunaan pembelajaran melalui metode diskusi kelompok pada mata pelajaran IPA dapat meningkatkan hasil belajar siswa. Hal ini dibuktikan dengan adanya peningkatan ketuntasan hasil belajar pada pra siklus, siklus I dan siklus II. Selain itu, motivasi siswa dalam belajar juga mengalami perubahan yang dibuktikan dengan siswa merasa senang dalam melakukan kerjasama kelompok dan berdiskusi. Hasil pembelajaran mengalami peningkatan sehingga indikator keberhasilan telah tercapai karena siswa yang mengalami ketuntasan belajar lebih dari $75 \%$.

Hasil penelitian ini senada dengan riset Faqih (2014) yang menemukan bahwa ternyata dengan metode kooperatif STAD pada pembelajaran IPA untuk materi penggolongan hewan berdasarkan jenis makanannya pada siswa kelas IV SD hasiInya mencapai kemajuan yang menggembirakan; pada siklus I nilai rata-rata siswa 64,58 dengan ketuntasan 33\% sedangkan pada siklus II menjadi 80,83 (nilai rata-rata) dengan ketuntasan $83 \%$. Kelompok I pada siklus I belum mendapat predikat tapi pada siklus II mendapat predikat kelompok baik (good team), sedangkan untuk kelompok II, mendapat penghargaan kelompok super (super team) pada siklus II yang sebelumnya pada siklus I dengan julukan kelompok baik (good team). Untuk kelompok III dan IV pada siklus I berjulukan kelompok baik menjadi kelompok hebat (great team) pada siklus II. Jadi semua kelompok telah bekerjasama dengan baik. Secara umum skor perkembangan siswa mengalami peningkatan pada tiap putaran, sehingga penghargaan kelompok juga meningkat.

Hasil riset ini senada pula dengan penelitian Rustiningsih (2018) yang menemukan bahwa dengan diterapkannya strategi card sort pada mata pelajaran IPA pokok bahasan penggolongan hewan berdasarkan jenis makanannya dapat meningkatkan hasil belajar siswa kelas III di MI Ma'arif NU 01 Karanggambas.

\section{SIMPULAN}

Berdasarkan hasil penelitian dapat disimpulkan bahwa pembelajaran IPA dengan menerapkan metode diskusi kelompok terbukti dapat meningkatkan aktivitas dan hasil belajar menggolongkan hewan berdasarkan jenis makanannya pada siswa kelas IV SD 1 Sidorekso Semester I Tahun Pelajaran 2015/2016.

\section{DAFTAR PUSTAKA}

Arikunto Suharsini, 1998. Prosedur Penelitian suatu Pendekatan Praktik (Edisi Revisi IV). Jakarta: Rineka Cipta.

Faqih, Abdul. 2014. Meningkatkan Kemampuan Menggolongkan Hewan Berdasarkan Jenis Makanannya Melalui Model Pembelajaran Kooperatif STAD Siswa Kelas IV SDN Mojokerto. Gamatika, V (I): $81-88$

Hamdani. 2011. Strategi Belajar Mengajar. Bandung: CV Pustaka Setia.

Rusman, 2012. Model-model Pembelajaran Mengembangkan Profesionalisme Guru. Jakarta: Rajawali Pers.

Rustiningsih, R. 2018. Peningkatan Hasil Belajar IPA Pokok Bahasan Penggolongan Hewan Berdasarkan Jenis Makananannya Menggunakan Strategi Card Sort Bagi Siswa Kelas III MI Ma'marif NU 01 Karanggambas Padamara Purbalingga Tahun Pelajaran 2017/2018. Skipsi. Purwokerto: IAIN Purwokerto. 